\title{
COMPARATIVE ANALYSIS OF DIFFERENT FINITE ELEMENT MODELS OF THE SOIL-BURIED ARCH BRIDGE INTERACTION
}

\section{KOMPARATIVNA ANALIZA MODELA INTERAKCIJE TLA I LUČNOG MOSTA SA ZEMLJANOM ISPUNOM ZASNOVANIH NA MKE}

\author{
Konstantin KAZAKOV \\ Lena MIHOVA \\ Doncho PARTOV
}

ORIGINALNI NAUČNI RAD ORIGINAL SCIENTIFIC PAPER

UDK:624.6:624.131.5 doi:10.5937/GRMK1904015K

\section{INTRODUCTION}

Comparative analysis is made of different static schemes and finite element models of the buried arch bridge with span of $15.29 \mathrm{~m}$ which is built in a railwayroad junction "Tri Voditsi" situated between the villages Tri Voditsi and Novo Selo in Bulgaria. The bridge is composed of 8 arches which consist of 24 prefabricated reinforced C50/60 concrete elements. The prefabricated elements are used for part of the foundations, for external retaining $0.60-0.35 \mathrm{~m}$ thick walls and for a 0.35 $\mathrm{m}$ thick vault plate. The foundation is constructed of two strips with width of $4.0 \mathrm{~m}$ and average thickness of 0.60 $\mathrm{m}$. The prefabricated strips are the half of the foundation inside of the arch structure. The part of the foundation is done on site of concrete C35/45. Photos of the bridge in construction phase and in service phase are presented in Figure 1.

The following two static schemes of bridge structure are considered:

- A continuous static scheme i.e. the connection between all structure elements is rigid;

- A static scheme of hinged connection between the retaining walls and the vault plate. The hinged connection does not bear a bending moment.

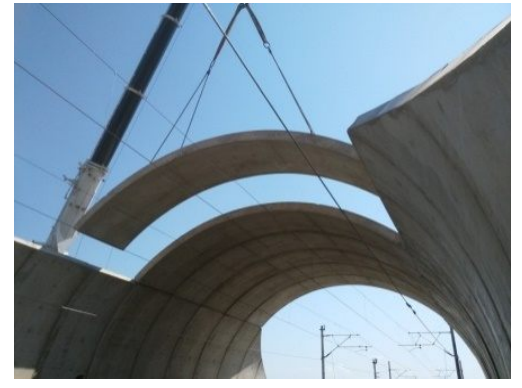

(a)

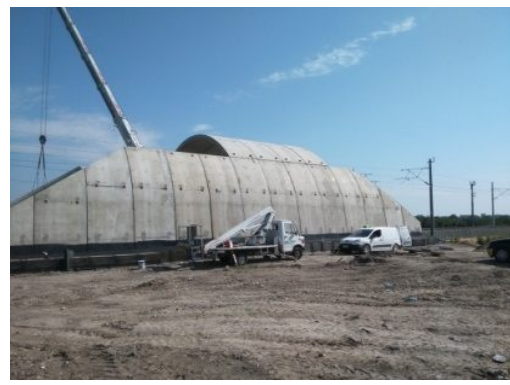

(b)

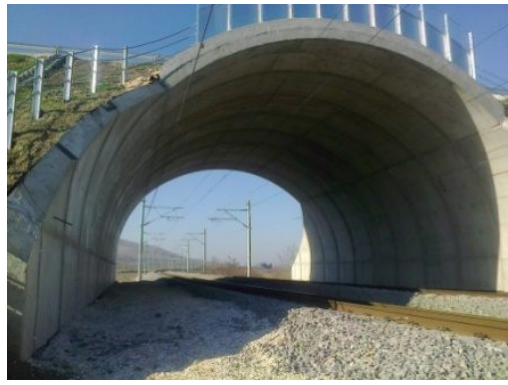

(c)

Figure 1. The bridge in construction period $(a, b)$ and in service period (c)

Konstantin Kazakov, Prof. DSc, University of Structural Engineering and Architecture, Sofia, Bulgaria, kazakov@vsu.bg Lena Mihova, Prof. PhD, University of Architecture, Civil Engineering and Geodesy, Sofia, Bulgaria, 1 mihova@yahoo.com

Doncho Partov, Prof. PhD, University of Structural Engineering and Architecture, Sofia, Bulgaria.partov@vsu.bg 
There are different approaches for modeling the soilstructure interaction in the finite element (FE) method [1]. The Winkler spring model is the most frequently applied in FE analyses. The main reason of this conclusion is the simplicity of this model and the fact that it is developed in most of the computer software products for structural analysis. The stiffness of the Winkler springs is determined using subgrade reaction moduli. This approach is applied in a previous analysis of the bridge structure using Autodesk Robot software [2] where the calculation of the subgrade reaction moduli is done according to the Menard theory [3]. Here are mentioned some Bulgarian researches based on the application of the Winkler spring model for the interaction of soil and different kinds of structures: shallow foundations [4], [5]; raft-pile foundation [6]; bridge support structures [7], [8]; retaining structures [9], [10].

The state-of-the-art approaches for modeling the soil-structure interaction consider the behavior both the structure and the soil body around the structure. For this purpose it is necessary to perform a finite element discretization of both the structure and the soil body and use appropriate constitutive models for the different materials and their contact. Advanced constitutive models are developed on the base of theoretical and experimental achievements in the soil mechanics. They take into account complex and highly varied mechanical behavior of the materials and use a lot of parameters. It is necessary to perform accurate experimental procedures and sensitivity analyses for identification of the constitutive parameters. A review of constitutive models for soil material is presented in reference [11]. Constitutive parameters of improved soil materials by advanced technologies are presented in [12], [13], [14], [15]. Features of the dynamic soil behavior and dynamic soil parameters are discussed in [16], [17], [18].

The stress-strain behaviour of the structure, the settlement and the bearing capacity of the soil ground are evaluated in construction and service periods of the bridge. The self-weight loading of the backfill and traffic loading of the road above the bridge are taken into account in the FE analyses performed by the Plaxis 2D software. Considerations about requirements of Eurocodes are discussed.

\section{FINITE ELEMENT MODELING}

\subsection{Finite element discretization, boundary and hydraulic conditions}

Plane strain condition in finite element modeling of the bridge is assumed. It means that all used finite elements have dimension perpendicular to the cross section plane equal to 1 . The cross section plane is denoted with $x y$.

Two alternative types of finite elements are used for the bridge structure (Figure 2): 15-node triangular plate elements (Figure $2 \mathrm{a}, \mathrm{b}$ ) and 5-node linear beam elements with width of 1 (Figure $2 \mathrm{c}$ ). The plate elements are formulated in normal and shear stresses. The beam elements are formulated in bending moments, axial and shear forces. The latter approximation is suitable because the output data include forces which allow designing the structure easily according to codes. A rotation stiffness of zero is defined in the beam joints of hinges. The hinge connection is simulated by a short beam element.

The rectangular soil body with width of $50 \mathrm{~m}$, height of $20 \mathrm{~m}$ and thickness of $1 \mathrm{~m}$ is discretized with triangular plate elements with two node parameters: displacements $U_{x}$ and $U_{y}$ in $x y$ plane. Boundary conditions involve zero horizontal displacement, $U_{x}$, and zero vertical displacement, $U_{y}$ (Figure 3 ). In the same figure the ground water level is denoted with WL.

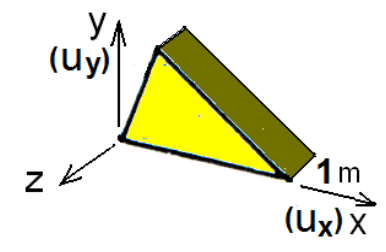

(a)

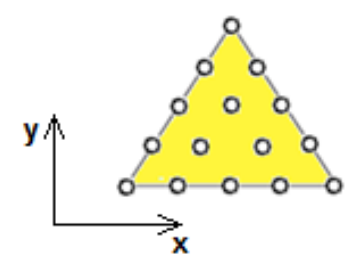

(b)

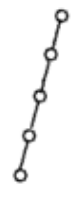

(c)

Figure 2. 15-node plane strain finite element $(a, b)$ and 5-node beam element (c)

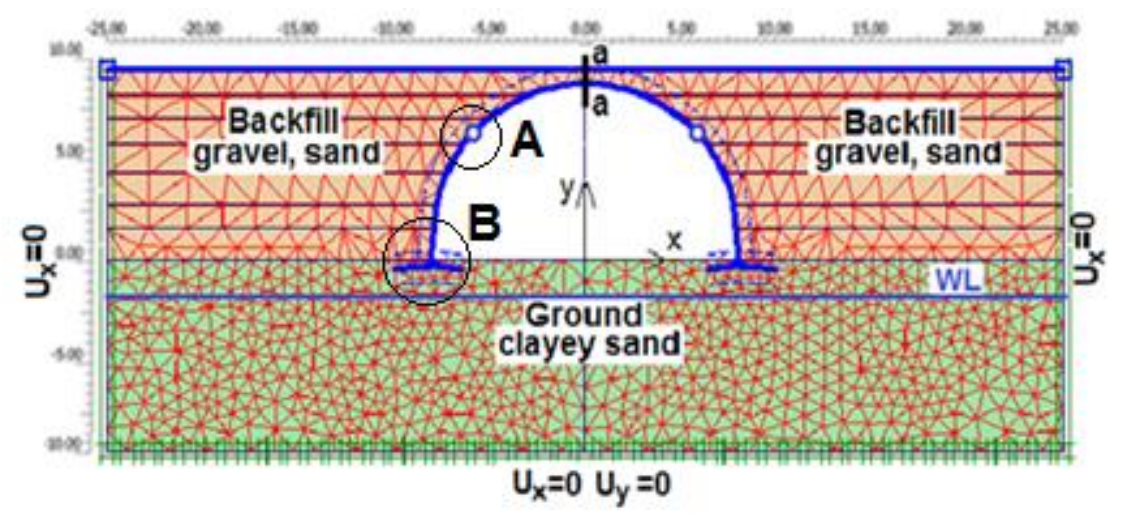

Figure 3. FE mesh of the plane strain model with boundary conditions $\left(U_{x}, U_{y}\right)$ and hydraulic conditions $(W L)$ 


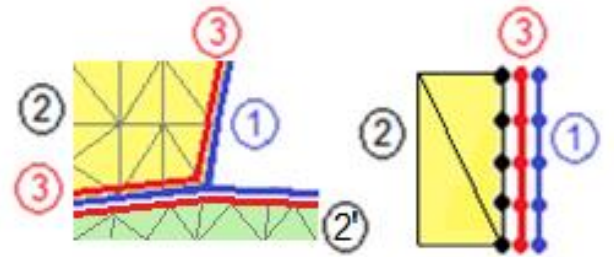

1-concrete beam FE

1 '-concrete plane strain FE

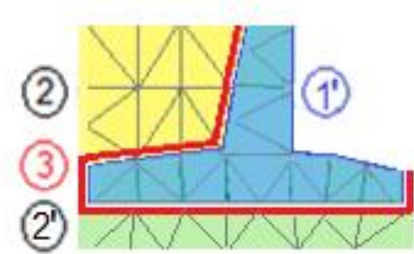

(2)

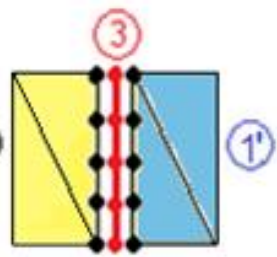

$2,2^{\prime}$-soil plane strain $\mathrm{FE}$

3 -interface $\mathrm{FE}$

Figure 4. Detail B from Fig. 3: Two approaches for FE modeling of soil-structure interaction

The soil-structure contact is modeled by interface elements of thickness closed to zero (Figure 4). The role of the interfaces is to reduce the friction in soil-structure contact compared to the friction in the soil. In Plaxis software the parameter which relates the shear strength of the soil to the shear strength in the interfaces is $R_{\text {inter. }}$ Here the value $R_{\text {inter }}=0.5$ is assumed. Some alternative approximations of soil-structure interaction are suggested in references [19], [20].

Figure 5 presents FE modeling of rigid connection and hinged connection in bridge structure (see detail $A$ in Figure 3). These two variants of static scheme are analyzed.

The bridge structure is undergone live traffic loads from the road which is built on the top of the backfill. The thickness of the backfill at the top of the bridge is only $0,50 \mathrm{~m}$. The traffic loads are simulated by the model LM1 according to Eurocode 1[21] and its Bulgarian Annex. According to this model the carrigeway is divided into notional lanes. The loading of each lane is composed of concentrated loads (Tandem System TS) and uniformly distributed load (System UDL). The most unfavorable loading is located on the lane number 1 represented in Figure 6 . For the study here the concentrated loads are approximated as a distributed load $q_{2}$ and the total distributed traffic load $\left(q_{1}+q_{2}\right)$ is applied pseudostatic. Different states of the total traffic load are taken into consideration.

\subsection{Constitutive laws for the bridge and soil materials}

The constitutive law is a mathematical description of stress-strain behaviour of the materials in response to the applied loads.

Hooke's law of linear, isotropic elasticity is used for modeling the concrete bridge structural elements. Input material parameters involved in equations of stressstrain relationship are only two - Young's modulus, E, and Poisson's ratio, $u$. Here are used two alternative constitutive models for the soil materials: the linear elastic-perfectly plastic Mohr-Coulomb's model and the advanced elastic-plastic Hardening-Soil model.

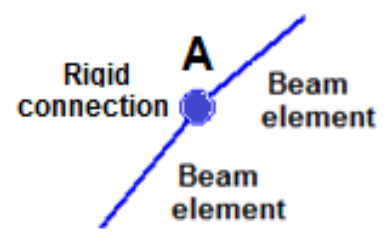

(a)

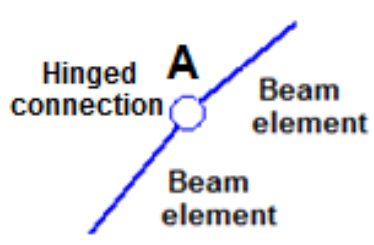

(b)

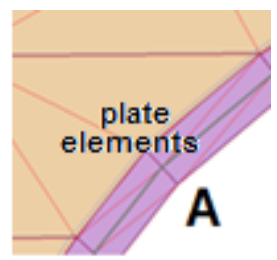

(c)

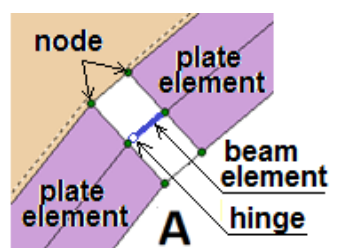

(d)

Figure 5. Detail A from Fig. 3 for connection between structural elements: (a) Rigid connection between beams; (b) Hinged connection between beams; (c) Rigid connection between plates; (d) Hinged connection between plates

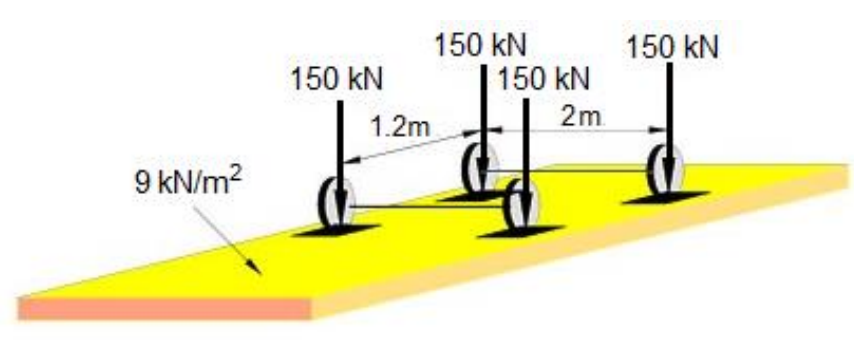

(a)

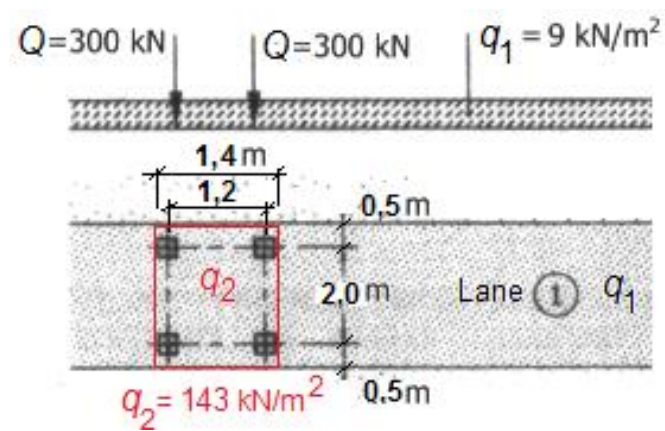

(b)

Figure 6. Model LM1 for road traffic loading: (a) TS and UDL systems;

(b) Approximation of the TS system as a distributed load $q_{2}$ 


\subsubsection{Mohr-Coulomb's soil model (M-C)}

According to M-C model, the stresses are proportional to the strains until the yield point is reached. The stress state corresponding to the yield point is defined by Mohr-Coulomb's yield function, $F$. The latter is represented as a hexagonal cone and it is shown in Figure 7. The plastic strain increments are determined using the flow rule defined with a prescribed function of the effective stresses, known as plastic potential, $Q$. The flow rule is termed associated flow rule when the plastic potential is equal to the yield function, i.e. $F=Q$. This is the classical form of plasticity, introduced by Von Mises (1928), which postulates that the direction of the vector of the plastic strain increment is perpendicular to the yield surface.

The flow rule is connected to the volume increase caused by the shearing during the plastic flow, so called dilatancy. However, the theory of associated plasticity with the Mohr-Coulomb's yield criterion predicts a dilatancy rate of the soil materials far greater than the one observed in real soil. For remediation of this inaccuracy of the model, the function of the plastic potential is chosen with the same form as the yield function, but the internal friction angle, $\varphi$, is replaced by the dilatancy angle, $\psi$. The dilatancy angle controls the volume change of the material undergoing plastic deformation. The dilatancy angle of the soil actually varies during the plastic deformation and it has values less than the value of the internal friction angle. The plastic volumetric strain increment is proportional to $\sin \psi$ and, consequently, is smaller than the ones predicted by the associative model. The flow rule corresponding to the case of $Q \neq F$ is known as a non-associated flow rule. The plastic deformation behavior of real soil obeys the non-associated flow rule. A constant rate of dilation and, respectively, a constant dilatancy angle of the soil, are often assumed in practice. In absence of laboratory or field data, the dilatancy angle, $\psi$, value can be selected in the range $0 \leq \psi \leq \varphi / 3$ [22]. The M-C model involves five input material parameters: $E$ and $v$ for the soil elasticity, $\varphi$ and $c$ for the soil plasticity and $\psi$ - the angle of dilatancy.

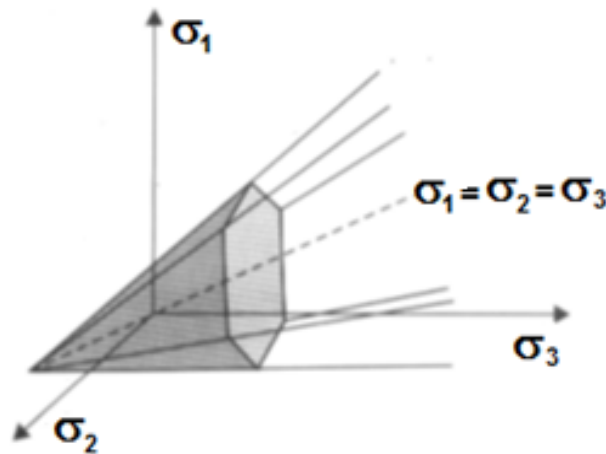

(a)

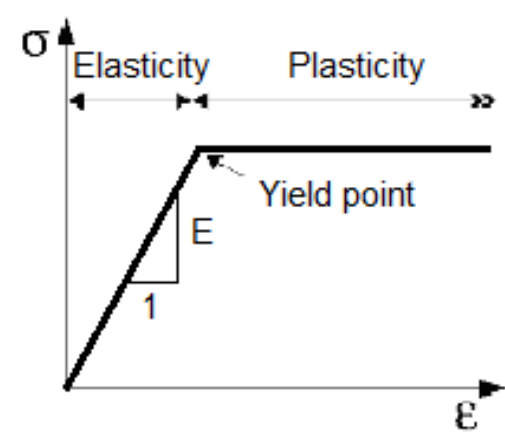

(b)

Figure 7. Mohr-Coulomb's model: (a) Yield surface in principal stress space; (b) Stress-strain curve and definition of E-modulus

Table 1. M-C model parameters of the backfill material and clayey sand ground

\begin{tabular}{|l|c|c|c|c|}
\hline \multicolumn{1}{|c|}{ Parameter } & Symbol & Dimension & Backfill & Clayey sand \\
\hline Unit weight of unsaturated soil & $\gamma$ unsat & $\mathrm{kN} / \mathrm{m}^{3}$ & 18 & 18 \\
\hline Unit weight of saturated soil & $\gamma$ sat & $\mathrm{kN} / \mathrm{m}^{3}$ & - & 20 \\
\hline Young's modulus & $E$ & $\mathrm{kN} / \mathrm{m}^{2}$ & 50000 & 20000 \\
\hline Poisson's ratio & $U$ & - & 0,3 & 0,3 \\
\hline Friction angle & $\varphi$ & 0 & 38 & 29 \\
\hline Dilatancy angle & $\psi$ & 0 & 8 & 0 \\
\hline
\end{tabular}




\subsubsection{Hardening Soil model (HS)}

HS model is an advanced constitutive conception simulating the behavior of different types of soil [23]. The description of the model presented here is according to the reference [24]. As for the Mohr-Coulomb's model, limiting states of stress are described by means of friction angle, $\varphi$, the cohesion, $c$, and the dilatancy angle, $\psi$. However, the soil stiffness is defined much more accurately by involving three different input stiffnesses: the triaxial loading stiffness, $E_{50}$, the triaxial unloading stiffness, $E_{\text {ur, }}$ and the oedometer loading stiffness, $E_{\text {oed. }}$ HS model also takes into account stressdependency of the stiffness that means that all stiffnesses increase with pressure, i.e. the soil is hardening. The yield surface is not fixed in principal stress space, but it can expand due to plastic straining. The yield surface of the HS model in principal stress space is represented in Figure $8 \mathrm{a}$. Two types of hardening are possible: shear hardening and compression hardening. The shear hardening is used to model irreversible plastic strains due to primary deviatoric loading. Compression hardening is used to model irreversible plastic strains due to primary compression in oedometer loading and in isotropic loading. Hyperbolic Duncan-Chang's relationship is assumed between the axial strain and the deviatoric stress for the standard drained triaxial test [25] (Figure 8b).

The basic characteristics of the HS model can be generalized as follows:

1) Stress dependent stiffness;

2) Hyperbolical stress-strain relation in primary loading for triaxial standard drained test;

3) Plastic straining due to primary deviatoric loading;

4) Plastic straining due to primary compression;

5) Elastic unloading/reloading;

6) Failure according to the Mohr-Coulomb's failure criterion.

The HS model has 15 input parameters including already mentioned basic parameters. The additional parameters of the HS model for material of the bridge soil body are shown in Table 2.

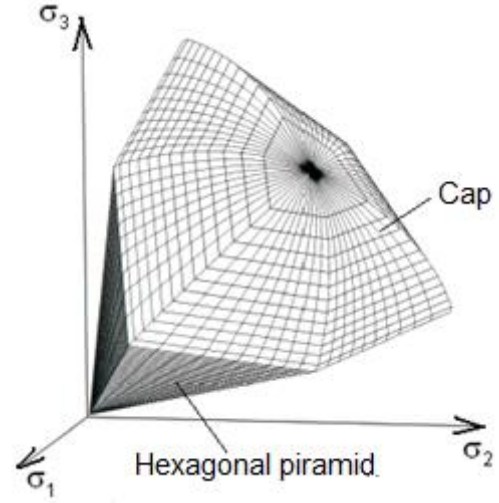

(a)

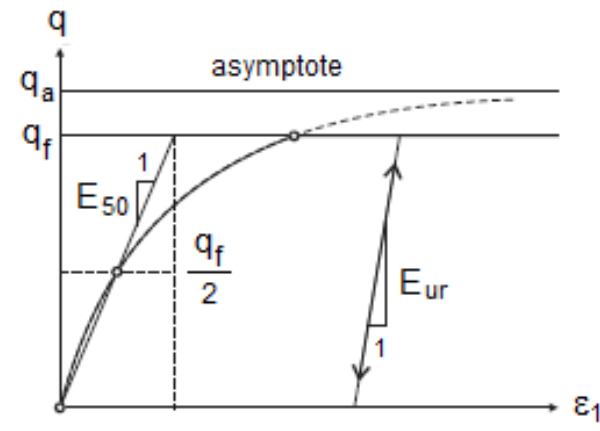

(b)

Figure 8. Hardening Soil model: (a) Yield surface in principal stress space;

(b) Stress-strain curve for triaxial standard drained test and definition of E-moduli

Table 2. HS model parameters of the backfill material and clayey sand ground

\begin{tabular}{|l|c|c|c|c|}
\hline \multicolumn{1}{|c|}{ Parameter } & Symbol & Dimension & Backill & $\begin{array}{c}\text { Clayey } \\
\text { sand }\end{array}$ \\
\hline Reference stress for stiffnesses & $p_{\text {ref }}$ & $\mathrm{kN} / \mathrm{m}^{2}$ & 100 & 100 \\
\hline Tangent stiffness for primary oedometer loading & $E_{\text {oed,ref }}$ & $\mathrm{kN} / \mathrm{m}^{2}$ & 50000 & 20000 \\
\hline Secant stiffness in standard drained triaxial test & $E_{50, \text { ref }}$ & $\mathrm{kN} / \mathrm{m}^{2}$ & 50000 & 20000 \\
\hline Unloading/reloading stiffness & $E_{\mathrm{ur}, \mathrm{ref}}$ & $\mathrm{kN} / \mathrm{m}^{2}$ & 150000 & 60000 \\
\hline Poisson's ratio for unloading/reloading & $V_{\mathrm{ur}}$ & - & 0,2 & 0,2 \\
\hline Power for stress-level dependency of stiffness & $m$ & - & 0,5 & 0,6 \\
\hline Coefficient of lateral earth pressure & $K_{0}$ & - & 0,384 & 0,515 \\
\hline Failure ratio & $R_{\mathrm{f}}$ & - & 0,9 & 0,9 \\
\hline
\end{tabular}




\subsection{Considerations of Eurocodes}

The Eurocodes are the current design codes in Bulgaria. The Eurocodes are based on the limit state design approach using partial factors for actions/effects of actions, material parameters and resistances. Eurocode 7 for geotechnical design [26] includes only general concepts for analysis of the soil-structure interaction. There are some clarifying books about the design according to Eurocode 7 [27], [28]. Bearing capacity analysis of the soil is the most important geotechnical analysis because it considers many parameters of the foundations, loading and soil materials. The Eurocode's requirements of the soil bearing capacity analysis and results from commonly used formulae for shallow foundations are presented in references [29], [30], [31]. The determining of the bearing capacity in case of presence of structural elements in soil body are discussed in references [32], [33].

The purpose of the present paper is to accent on the advantages and disadvantages of the different static schemes and numerical models of the bridge structure and its interaction with soil ground and filling material. That is why the analyses are performed without using partial factors according to Eurocodes. Special attention is given to bearing capacity analysis of the soil using unfactored resistance parameters of the soil.

\subsection{Finite element analyses}

\subsection{1 "In situ" stress analysis}

"In situ" stress analysis defines the initial stress state of the ground while the initial displacements of the ground are equal to zero. The initial stress state of the ground involves values of normal vertical and horizontal stresses due to self-weight of the soil and values of water pressure. In the present case the ground surface is horizontal. The initial vertical effective stresses are determined by the expression $\sigma_{y, 0}=\gamma . h$, where $\gamma$ is the soil unit weight, $h$ is depth below the ground surface. The initial horizontal effective stresses are determined by the expression $\sigma_{\mathrm{x}, 0}{ }^{\prime}=K_{0} \cdot \sigma_{\mathrm{y}, 0^{\prime}}$, where $K_{0}$ is coefficient of lateral pressure at rest calculated by Jaky's empirical formula $K_{0}=1-\sin \varphi$. The water pressure is calculated by the formula $p_{w}=\gamma_{w} \cdot h_{w}$, where $\gamma_{w}$ is unit weight of water, $h_{w}$ is depth below the water level.

Diagrams of the initial stresses in the soil ground are shown in Figure 9.

\subsubsection{Construction period of the bridge}

The construction period of the transport junction, part of which is the building of the arch bridge structure, is simulated by the following sequence of states (Fig. 9):

- State 1: Construction of the arch bridge structure by precast elements;

- State 2 - State 8: Backfilling;

- State 9: Construction of the road above the bridge.

The asphalt road above the bridge is modelled in stage 9 by elastic beam finite elements with the following material parameters: unit weight $\gamma=22 \mathrm{kN} / \mathrm{m}^{3}$, Young's modulus $E=150.10^{5} \mathrm{kN} / \mathrm{m}^{2}$ and Poisson's ratio $u=0.2$.

\subsubsection{Service period of the bridge}

The live loading of the bridge structure due to the road traffic is simulated by a consequence of states (State 10 - State 13). All states consist of continuous uniformly distributed load $q_{1}=-9 \mathrm{kN} / \mathrm{m}^{2}$ and partial distributed load $q_{2}=-143 \mathrm{kN} / \mathrm{m}^{2}$. Different locations of the load $q_{2}$ are accepted (Figure 11).

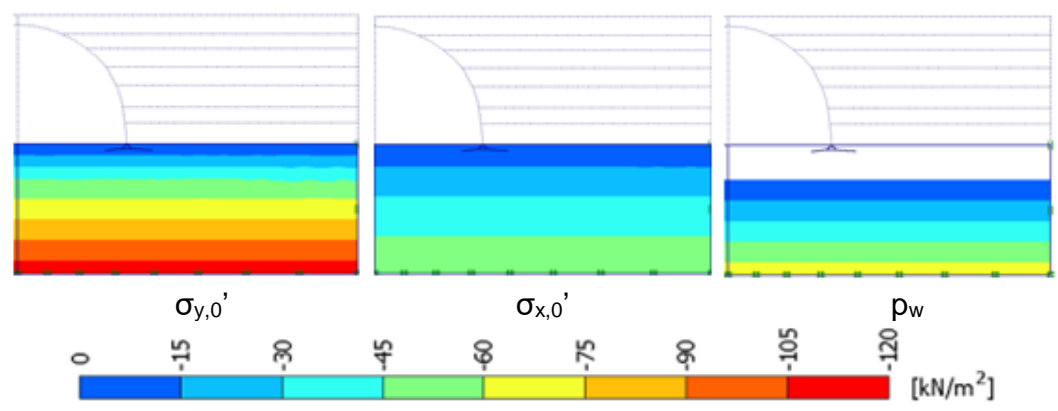

Figure 9. Diagrams of the initial stresses in the soil ground

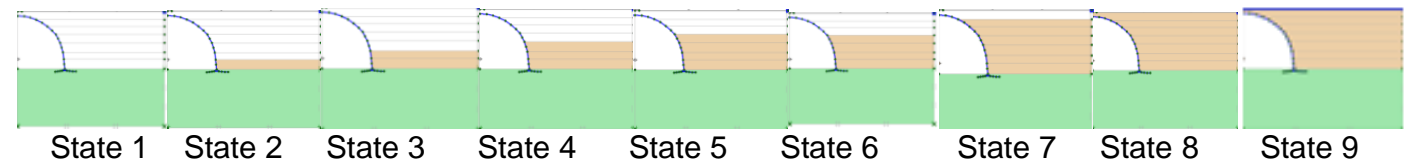

Figure 10. States in construction period

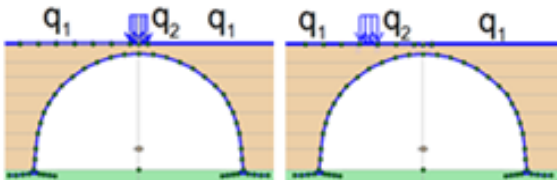

State 10
State 11

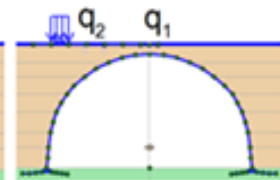

State 12

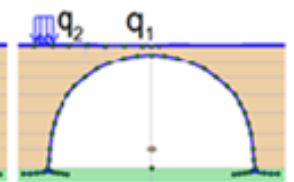

State 13

Figure 11. Simulation of the traffic live loading of the bridge structure 


\subsubsection{Bearing capacity analysis of the soil ground}

The finite element method offers some advanced computer techniques for bearing capacity analysis. The main advantage is the ability to develop failure mechanism considering the deformation and the strength properties of the soil. Here is used the shear strength reduction technique (SSR) included in Plaxis 2D software. The soil Mohr-Coulomb's strength parameters (the friction angle, $\varphi$, and the cohesion, $c$ ) are reduced artificially and progressively until the state of soil failure is reached. The bearing capacity safety factor, $F_{\mathrm{s}}$, is deemed the factor by which the soil strength parameters are reduced so that failure is reached [34]. The SSR technique is very suitable for bearing capacity analysis at cases of complex geotechnical conditions and complex loading [35].

\section{RESULTS FROM FINITE ELEMENT ANALYSES}

\subsection{Results from the models of continuous bridge}

Table 3 presents results of bending moment, axial force and normal stresses in the bridge structure obtained from solutions of different FE models.

Table 3. Results from FE analyses of State 9 in cross section a-a (see Figure 3) of the bridge

\begin{tabular}{|c|c|c|c|c|c|}
\hline Type of modeling & $\begin{array}{c}M_{\mathrm{a}-\mathrm{a}} \\
(\mathrm{kNm})\end{array}$ & $\begin{array}{c}N_{\mathrm{a}-\mathrm{a}} \\
(\mathrm{kN})\end{array}$ & $\begin{array}{c}\sigma_{\mathrm{x}, \mathrm{a}-\mathrm{a}} \text { top } \\
(\mathrm{kPa})\end{array}$ & $\begin{array}{c}\sigma_{\mathrm{x}, \mathrm{a}-\mathrm{a}} \text { down } \\
(\mathrm{kPa})\end{array}$ & $\begin{array}{c}U_{\mathrm{y}, \mathrm{a}-\mathrm{a}} \\
(\mathrm{m})\end{array}$ \\
\hline Soils - HS model; Bridge - plate FE & 71 & -363 & 2419 & -4497 & -0.07 \\
\hline Soils - HS model; Bridge - beam FE & 65 & -338 & 2120 & -4052 & -0.08 \\
\hline Soils - MC model; Bridge - plate FE & 27 & -216 & 253 & -1955 & -0.06 \\
\hline Soils - MC model; Bridge - beam FE & 20 & -314 & 83 & -1877 & -0.07 \\
\hline
\end{tabular}

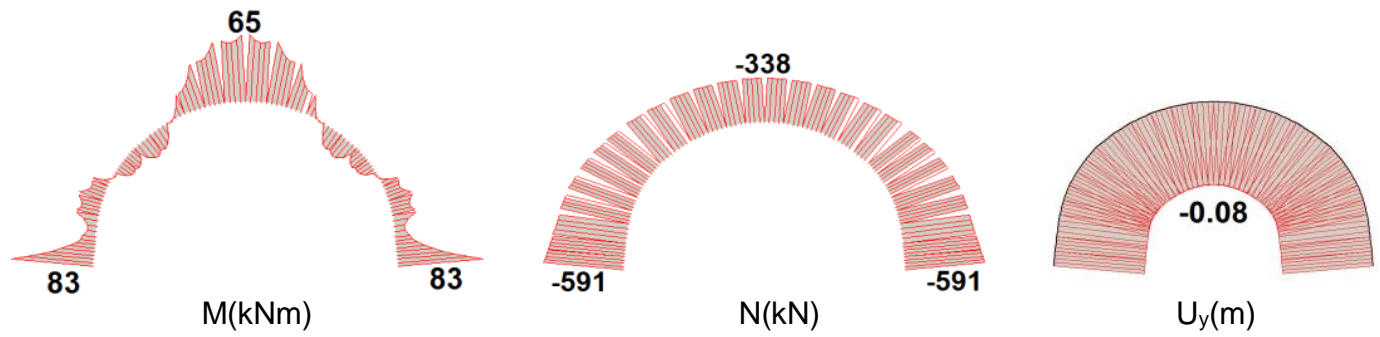

Figure 12. Type of modeling "Soils - HS model; Bridge - beam FE": Diagrams of bending moment M, axial force $N$ and displacement $U_{y}(m)$ as a result from FE analysis of State 9
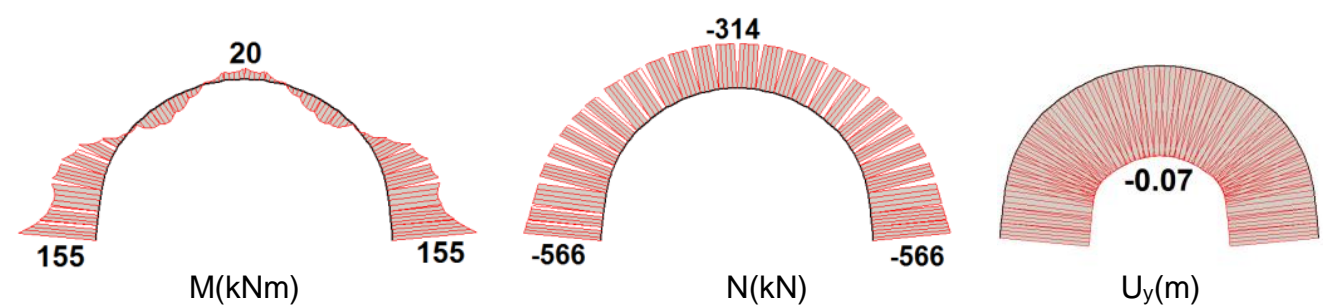

$\mathrm{N}(\mathrm{kN})$

$\mathrm{U}_{\mathrm{y}}(\mathrm{m})$

Figure 13. Type of modeling "Soils - MC model; Bridge - beam FE": Diagrams of bending moment M, axial force N and displacement $U_{y}$ as a result from FE analysis of State 9

Table 4. Results of FE analyses of State 10 in cross section a-a (see Fig. 3) of the bridge

\begin{tabular}{|l|c|c|c|c|c|}
\hline \multicolumn{1}{|c|}{ Type of FE modeling } & $\begin{array}{c}M_{\mathrm{a}-\mathrm{a}} \\
(\mathrm{kNm})\end{array}$ & $\begin{array}{c}N_{\mathrm{a}-\mathrm{a}} \\
(\mathrm{kN})\end{array}$ & $\begin{array}{c}\sigma_{\mathrm{x}, \mathrm{a}-\mathrm{a}}^{\text {top }} \\
(\mathrm{kPa})\end{array}$ & $\begin{array}{c}\sigma_{\mathrm{x}, \mathrm{a}-\mathrm{a}} \\
(\mathrm{kPa})\end{array}$ & $\begin{array}{c}U_{\mathrm{y}, \mathrm{a}-\mathrm{a}} \\
(\mathrm{m})\end{array}$ \\
\hline Soils - HS model; Bridge - plate FE & -30 & -455 & -2788 & 193 & -0.08 \\
\hline Soils - HS model; Bridge - beam FE & -37 & -507 & -3265 & 369 & -0.09 \\
\hline Soils - MC model; Bridge - plate FE & -92 & -354 & -5493 & 3469 & -0.08 \\
\hline Soils - MC model; Bridge - beam FE & -94 & -460 & -5928 & 3300 & -0.09 \\
\hline
\end{tabular}




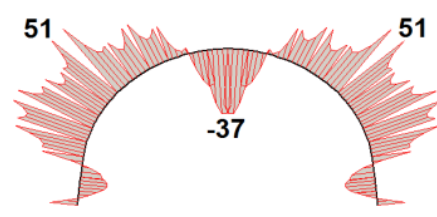

$\mathrm{M}(\mathrm{kNm})$

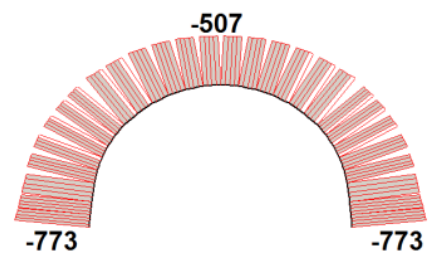

$\mathrm{N}(\mathrm{kN})$

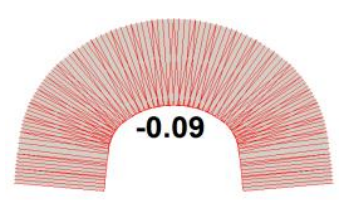

$\mathrm{U}_{\mathrm{y}}(\mathrm{m})$

Figure 14. Type of modeling "Soils - HS model; Bridge - beam FE": Diagrams of bending moment $M$, axial force $N$ and displacement $U_{y}$ as a result from FE analysis of State 10

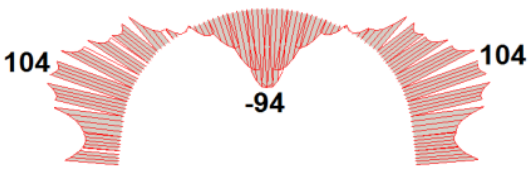

$\mathrm{M}(\mathrm{kNm})$

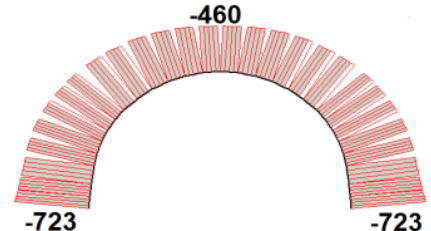

$\mathrm{N}(\mathrm{kN})$

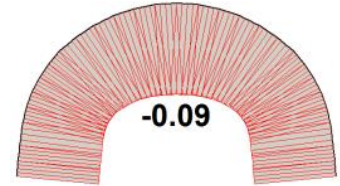

$\mathrm{U}_{\mathrm{y}}(\mathrm{m})$

Figure 15. Type of modeling "Soils - MC model; Bridge - beam FE": Diagrams of bending moment $M$, axial force $N$ and displacement $U_{y}$ as a result from FE analysis of State 10
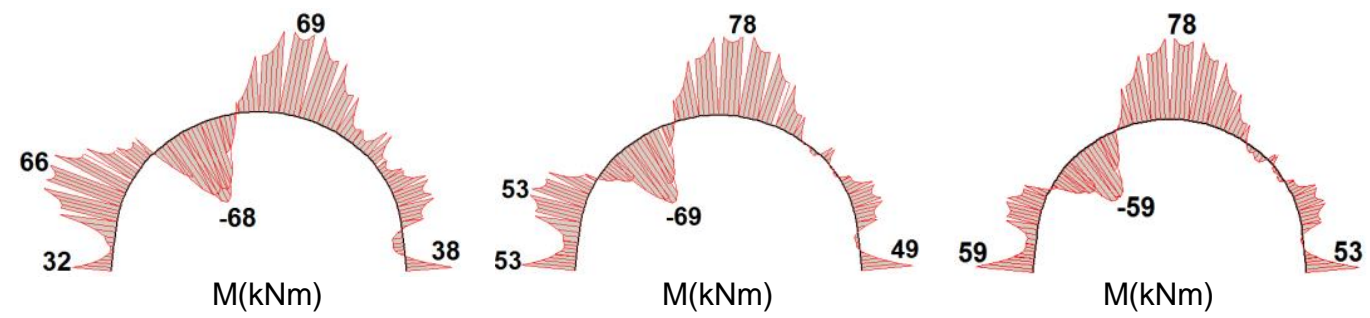

Figure 16. Type of modeling "Soils - HS model; Bridge - beam FE": Diagrams of bending moment $M$ as a result from FE analysis of States 11, 12, 13
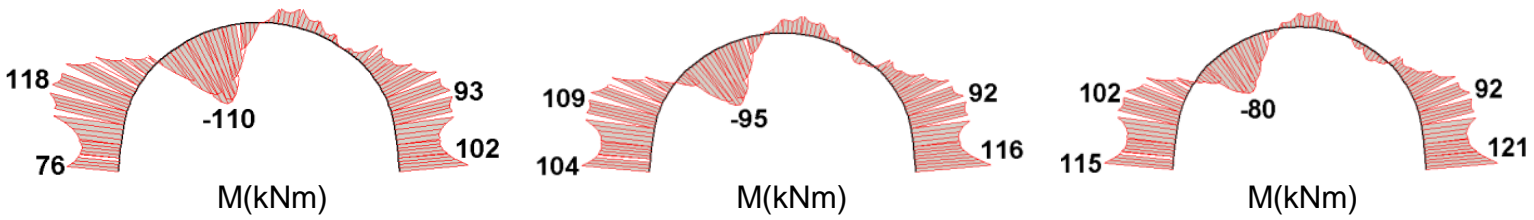

Figure 17. Type of modeling "Soils - MC model; Bridge - beam FE": Diagrams of bending moment $M$ as a result from FE analysis of States 11, 12, 13

Results for the bearing capacity safety factor, $F_{\mathrm{s}}$, obtained from solutions of the presented FE models are summarized in Table 5 and typical failure modes are shown in Figure 18.

Table 5. Values of bearing capacity safety factor, $F_{s}$

\begin{tabular}{|l|c|c|c|}
\hline \multirow{2}{*}{\multicolumn{2}{|c|}{ Type of FE modeling }} & \multicolumn{3}{c|}{$F_{\mathrm{s}}$} \\
\cline { 2 - 4 } & State 1 & State 9 & State 10 \\
\hline Soils - HS or MC model; Bridge - beam FE & 4.0 & 2.4 & 2.4 \\
\hline Soils - HS or MC model; Bridge - plate FE & 5.2 & 2.7 & 2.7 \\
\hline
\end{tabular}




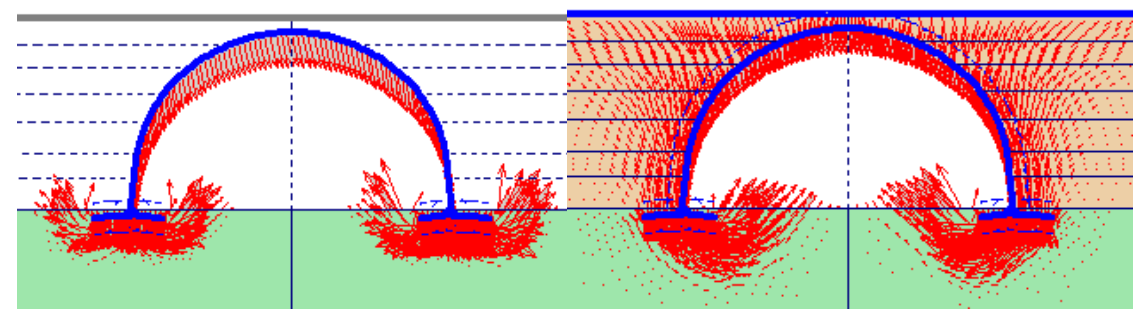

(a)

(b)

Figure 18. Failure modes presented by the vectors of deformation increments:

(a) State 1; (b) State 9 - State 13

\subsection{Results from the models of hinged bridge}

Table 6. Results from FE analyses of State 9 in cross section a-a (see Fig. 3) of the bridge

\begin{tabular}{|c|c|c|c|c|c|}
\hline Type of modeling & $\begin{array}{c}M_{\mathrm{a}-\mathrm{a}} \\
(\mathrm{kNm})\end{array}$ & $\begin{array}{c}N_{\mathrm{a}-\mathrm{a}} \\
(\mathrm{kN})\end{array}$ & $\begin{array}{c}\sigma_{\mathrm{x}, \mathrm{a}-\mathrm{a}} \\
(\mathrm{kPa})\end{array}$ & $\begin{array}{c}\sigma_{\mathrm{x}, \mathrm{a}-\mathrm{a}} \text { down } \\
(\mathrm{kPa})\end{array}$ & $\begin{array}{c}U_{\mathrm{y}, \mathrm{a}-\mathrm{a}} \\
(\mathrm{m})\end{array}$ \\
\hline Soils - HS model; Bridge - plate FE & 68 & -355 & 2297 & -4327 & $-0,066$ \\
\hline Soils - HS model; Bridge - beam FE & 71 & -340 & 2506 & -4449 & $-0,086$ \\
\hline Soils - MC model; Bridge - plate FE & -2 & -267 & -859 & -667 & $-0,063$ \\
\hline Soils - MC model; Bridge - beam FE & 6 & -311 & -595 & -1183 & $-0,071$ \\
\hline
\end{tabular}

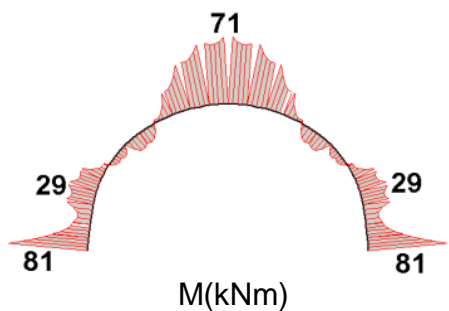

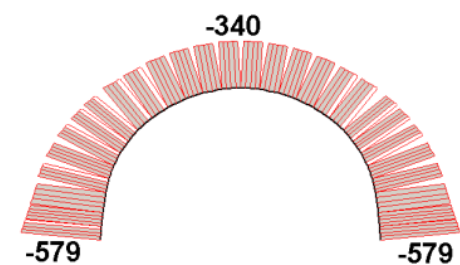

$\mathrm{N}(\mathrm{kN})$

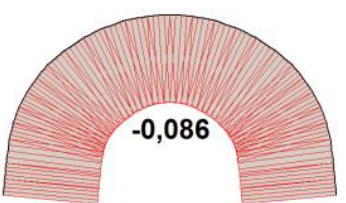

$\mathrm{U}_{\mathrm{y}}(\mathrm{m})$

Figure 19. Type of modeling "Soils - HS model; Bridge - beam FE": Diagrams of bending moment M, axial force $N$ and displacement $U_{y}(m)$ as a result from FE analysis of State 9

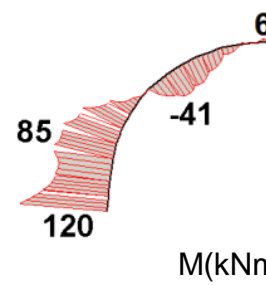

6

\section{$-41$}

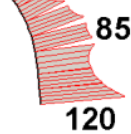

120

$-552$

$\mathrm{M}(\mathrm{kNm})$

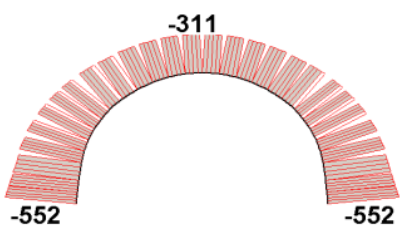

$\mathrm{N}(\mathrm{kN})$

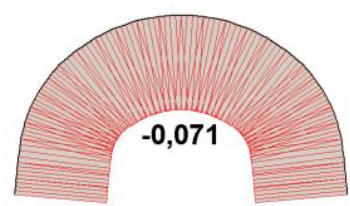

$\bigcup_{\mathrm{y}}(\mathrm{m})$

Figure 20. Type of modeling "Soils - MC model; Bridge - beam FE": Diagrams of bending moment M, axial force $N$ and displacement $U_{y}$ as a result from FE analysis of State 9

Table 7. Results from FE analyses of State 10 in cross section a-a (see Fig. 3) of the bridge

\begin{tabular}{|l|c|c|c|c|c|}
\hline \multicolumn{1}{|c|}{ Type of FE modeling } & $\begin{array}{c}M_{\mathrm{a}-\mathrm{a}} \\
(\mathrm{kNm})\end{array}$ & $\begin{array}{c}N_{\mathrm{a}-\mathrm{a}} \\
(\mathrm{kN})\end{array}$ & $\begin{array}{c}\sigma_{\mathrm{x}, \mathrm{a}-\mathrm{a}} \text { top } \\
(\mathrm{kPa})\end{array}$ & $\begin{array}{c}\sigma_{\mathrm{x}, \mathrm{a}-\mathrm{a}} \text { down } \\
(\mathrm{kPa})\end{array}$ & $\begin{array}{c}U_{\mathrm{y}, \mathrm{a}-\mathrm{a}} \\
(\mathrm{m})\end{array}$ \\
\hline Soils - HS model; Bridge - plate FE & -37 & -452 & -3119 & 534 & $-0,083$ \\
\hline Soils - HS model; Bridge - beam FE & -43 & -519 & -3589 & 623 & $-0,095$ \\
\hline Soils - MC model; Bridge - plate FE & -119 & -331 & -6790 & 4903 & $-0,083$ \\
\hline Soils - MC model; Bridge - beam FE & -121 & -465 & -7256 & 4598 & $-0,091$ \\
\hline
\end{tabular}




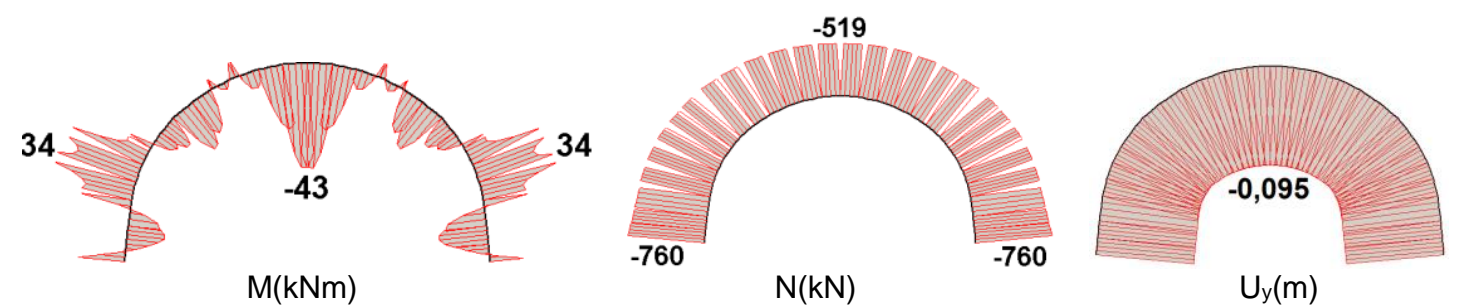

Figure 21. Type of modeling "Soils - HS model; Bridge - beam FE": Diagrams of bending moment $M$, axial force $N$ and displacement $U_{y}$ as a result from FE analysis of State 10
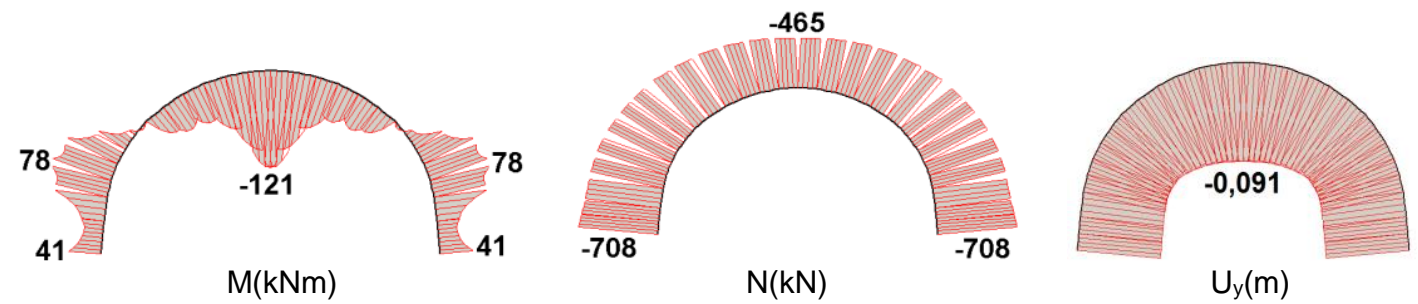

Figure 22. Type of modeling "Soils - MC model; Bridge - beam FE": Diagrams of bending moment $M$, axial force $N$ and displacement $U_{y}$ as a result from $F E$ analysis of State 10
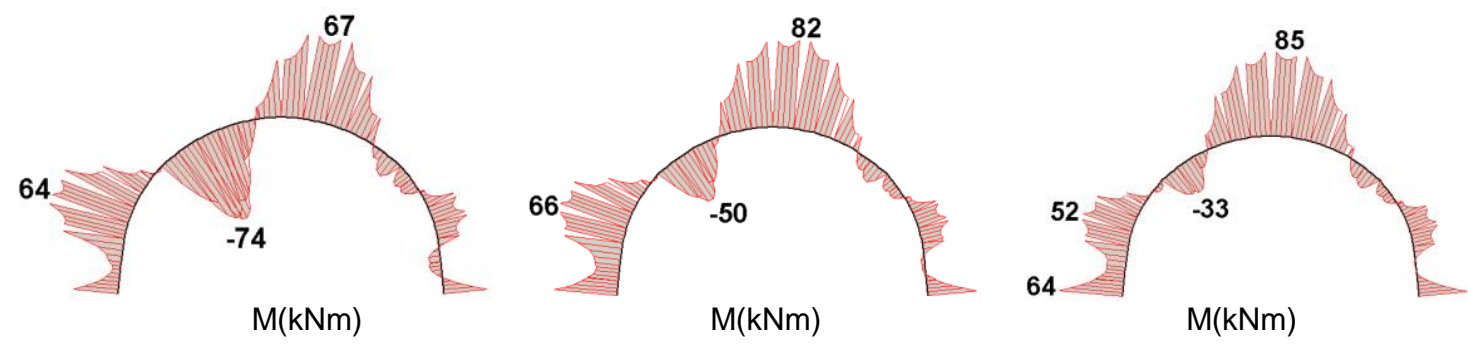

Figure 23. Type of modeling "Soils - HS model; Bridge - beam FE": Diagrams of bending moment $M$ as a result from FE analysis of States 11, 12, 13
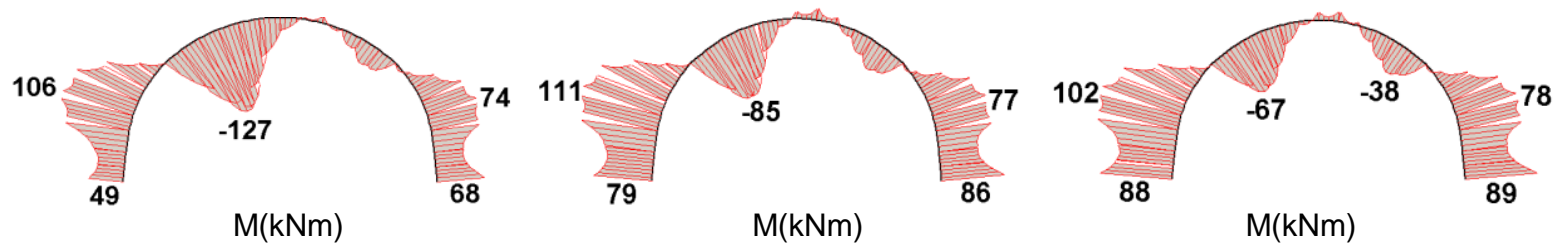

Figure 24. Type of modeling "Soils - MC model; Bridge - beam FE": Diagrams of bending moment $M$ as a result from FE analysis of States 11, 12, 13

Results for the bearing capacity safety factor, $F_{\mathrm{s}}$, obtained from solutions of the presented FE models are summarized in Table 8 and typical failure modes are shown in Figure 25.

Table 8. Values of bearing capacity safety factor, $F_{s}$

\begin{tabular}{|l|c|c|c|}
\hline \multirow{2}{*}{\multicolumn{1}{|c|}{ Type of FE modeling }} & \multicolumn{3}{c|}{$F_{\mathrm{s}}$} \\
\cline { 2 - 4 } & State 1 & State 9 & State 10 \\
\hline Soils - HS or MC model; Bridge - beam FE & 3,5 & 1,8 & 1,8 \\
\hline Soils - HS or MC model; Bridge - plate FE & 4,2 & 1,9 & 1,9 \\
\hline
\end{tabular}




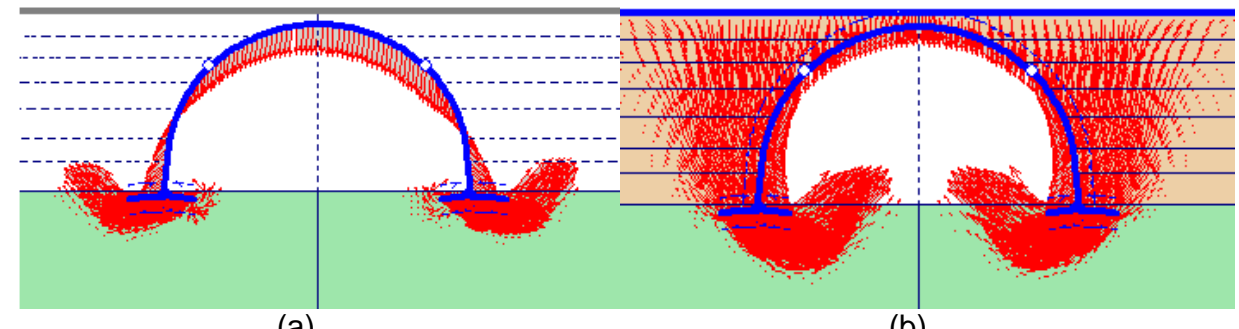

(a)

(b)

Figure 25. Failure modes presented by the vectors of deformation increments:

(a) State 1; (b) State 9 - State 13

\section{ANALYSIS OF THE RESULTS FROM FE MODELS}

\subsection{Analysis of the results from models of continuous bridge}

- The solutions which use models with beam elements for the bridge structure give from 1.1 to 1.35 times larger values of the bending moment than those obtained from the solutions with plate elements for the bridge structure.

- There are differences in the values of the axial force in the bridge structure obtained from different models. The solutions of the State 9 (the end of construction period) and State 10 (the first service state) which use models with beam elements for the bridge structure gives from 1.2 to 1.5 times larger values of the axial forces than those obtained with the solutions which use models with Plate elements for the bridge structure.

- The solutions which use models with beam elements for the bridge structure give from 1.1 to 1.2 times larger values of the vertical displacement of the bridge than those obtained with the solutions with Plate elements for the bridge structure.

- Hardening Soil (HS) constitutive model is an advanced conception in the soil mechanics. It uses more than 15 material parameters. Mohr-Coulomb (M-C) constitutive model is the most applicable classical theoretical model for the mechanical behavior of the soils.

- The differences between the values of bending moment in bridge structure obtained from the solution according to $\mathrm{HS}$ and $\mathrm{M}-\mathrm{C}$ constitutive models are about 2-3 times.

- HS constitutive model gives 1.1 times larger values of axial forces in bridge structure in comparison to $M-C$ constitutive model.

- M-C constitutive model gives from 1.1 to 1.2 times larger values of vertical displacement in bridge structure in comparison to HS constitutive model.

- The values of the vertical displacements in the bridge structure are $8.3-9.5 \mathrm{~cm}$ due to mainly the settlements of the ground.

- The lowest value of bearing capacity safety factor is $F_{\mathrm{s}}=2.4$ which means that there is not a risk of failure of the bridge.

\subsection{Analysis of the results from models of hinged bridge}

- The finite element solutions which use plate elements or beam elements for the bridge structure modeling obtain approximately same values of bending moments.

- There are differences in the values of the axial force in the bridge structure obtained from different models. The solutions of the State 9 (the end of construction period) and State 10 (the first service state) which use models with beam elements for the bridge structure give from 1.2 to 1.4 times larger values of the axial forces than those obtained with the solutions which use models with Plate elements for the bridge structure.

- The solutions which use models with beam elements for the bridge structure give from 1.1 to 1.3 times larger values of the vertical displacement of the bridge than those obtained from the solutions with plate elements for the bridge structure.

- There are significant differences between the values of bending moment in the bridge structure obtained from the solution according to $\mathrm{HS}$ and $\mathrm{M}-\mathrm{C}$ constitutive models for soil ground and filling material. The differences of bending moment increase from 2 to 10 times.

- HS constitutive model gives from 1.1 to 1.4 times larger values of axial forces in bridge structure in comparison to MC constitutive model.

- HS and MC constitutive models give similar results for the vertical displacements of the bridge structure.

- The bridge structure has high values of vertical displacements $(8-9 \mathrm{~cm})$ due to mainly the settlements of the ground.

- The lowest value of the bearing capacity safety factor is $F_{\mathrm{s}}=1.8$ which means that there is not a risk of failure of the bridge.

\subsection{Comparative analysis of the results}

Comparative analysis between the model of the bridge with two hinges developed here and the model of continuous bridge gives the following conclusions: 
- The differences between the two models of the bridge are larger when the $\mathrm{M}-\mathrm{C}$ constitutive law is used: the model with two hinges gives about 30\% larger bending moments and axial forces than the model of continuous bridge.

- The values of the vertical displacements of the bridge structure obtained from all solutions are too high and do not satisfy the serviceable limit state requirements. It is necessary to improve the soil ground or to build deep foundations of the structure.

- The model with two hinges gives 30\% lower values of the bearing capacity safety factor.

- The failure mechanism in the State 1 (the state of the bridge construction before the backfilling) is twosided in the case of continuous bridge and one-sided in the case of hinged bridge.

\section{CONCLUSIONS}

A new approach is applied for numerical modeling of the mechanical behavior of an arch bridged structure. The approach consists in using plane strain finite elements for the soil body and interface elements for the soil-structure contact. The numerical modeling is developed on the basis of two non-linear constitutive laws of the soil materials - the linear elastic-perfectly plastic Mohr-Coulomb's model and the advanced elasticplastic Hardening Soil model. They both are adapted in Plaxis software which is used for the accomplishment of the present research. The Hardening-Soil model is stateof-the-art scientific achievement which interprets the mechanical behavior of the soil materials with high accuracy using 15 material parameters.

Comparative analysis of the FE models shows that the numerical solutions based on the old classical concepts of the soil mechanics obtain considerably conservative results.

It is important to mention that the advanced soil constitutive models describe more precisely mechanical behavior of the soil because they use a lot of material parameters. But the correct application of the advanced models requires performing accurate experimental procedures and sensitivity analyses for identification of constitutive parameters.

\section{REFERENCES}

[1] Milev, N., (2014). Approaches for Consideration of the Soil-Foundation-Structure Interaction. Annual of the University of Architecture, Civil Engineering and Geodesy, Fascicule IV, Geotechnical Engineering, Vol. XLVI, Sofia.

[2] Summary of Design \& Analysis for Structure of the project "Tri Voditsi", RS, (2014). Sofia.

[3] Menard, L., (1975). The Menard Pressuremeter: Interpretation and Application of the Pressuremeter Test Results to Foundation Design, Sols-Soils, No. 26, Paris.

[4] Milev, N., (2013). A Simplified Soil-Single Footing Interaction Based on Winkler Foundation Model. International Conference on Earthquake Geotechnical Engineering (ICEGE2013), Istanbul.

[5] Tsvetanov, T., Mihov, Y., Mihova, L., (2003-2004). Structural analysis and calculation model of multistorey RC building. Annual of the University of Architecture, Civil Engineering and Geodesy, Fascicule IV, Geotechnical Engineering, Vol. XLI, Sofia.

[6] Tanev, T., Kerenchev, N., Manolov, A., Dimitrov, $H$., (2012). Analyzing the displacements of a pile frame to determine its transverse load-bearing capacity. Proc. of the 22-nd European Young Geotechnical Engineering Conference, EYGEC2012.Gothenburg, Sweden.

[7] Mihova, L., (2014).Computing models for design of a road bridge over the Litani River in Lebanon at partially existence of soil ground under the bridge slab. Proc. 14th International Scientific Conference VSU'2014, Sofia.

[8] Mihov, Y., Mihova, L., (2012). Behavior of pile retaining walls as abutments of temporary bridges during the construction of the Sofia metropolitan. Proc. of the Vth International Geomechanics Conference, Varna.

[9] Mihova, L., Mihov, Y., (2012). Design considerations and computing models of the zero cycle construction of the Mladost trade center. Proc. 70th Anniversary UACEG Int. Jubilee Conference UACEG2012: Science \& Practice, Vol. 3. Sofia.

[10] Mihova, L., Zayakova, H., (2015). Landslide supporting pile structures realized in Bulgarian road network. First Scientific-Applied Conference with International Participation "Reinforced concrete and masonry structures theory and practice", Sofia.

[11] Mihova, L., Tanev, T., (2015). Elastic and elastoplastic constitutive models in soil mechanics. Annual of the University of Architecture, Civil Engineering and Geodesy, Fascicule IV, Vol. XLVII, Sofia

[12] Kalcheva, I., Totsev, A., (2014). Rapid Impact Compaction for Civil Engineering Applications Compaction and Improving the Ground for High Embankments, VIII Regionalen Kongres Georeks, Skopje, Macedonia.

[13] Totsev, A., (2014). Application of Impact Compaction Method for Rreduction of the Ground Settlement. VII National Conference on Roads with International Participation, Sunny Beach, Bulgaria. 
[14] Totsev, A., Kerenchev, N., Parvanov, B., (2019). Foundation and Soil Improvements of the Subsoil under St. Ivan Rilski University Hospital Building or the Construction of a Cyberknife System Bunker. XVII ECSMGE, Reykjavik.

[15] Milev, N., (2019). Strengthening of the Raft Foundation of an Existing $\mathrm{RC}$ Building by Application of Jet-Grouting as Structural and Ground Improvement Technique. Eight Geotechnics in Civil Engineering Conference, Vrnjačka Banja, Serbia.

[16] Ivanov, I., (2008). Regarding some dynamic characteristics of the soils and the liquefaction potential of sands in Sofia. Proceedings 8th International Scientific Conference SGEM, Vol. II, Varna, Bulgaria.

[17] Milev, N., (2017). Small-Strain Behavior of Cohesionless Soils by Triaxial Tests and Dynamic Measurement Methods. Seventh Conf. Geotechnics in Civil Engineering Conference, Šabac.

[18] Milev, N., (2018). Static and Dynamic Evaluation of Elastic Properties of Sofia Sand and Toyoura Sand by Sophisticated Triaxial Tests - Journal for Research of Material sand Structures (ISSN 2217 8139), Belgrade, Serbia.

[19] Kostova, S., (2017). Improvement of methods for determining of soil parameters used in soilstructure interaction models - study of anchor foundations behavior. Dissertation for the degree of PhD, Todor Kableshkov University of Transport, Sofia.

[20] Milev, N., (2016). A Macroelement for Consideration of the Soil-Shallow FoundationSuperstructure Interaction Effect in Nonlinear Seismic Analysis. Fifth International Conference on Earthquake Engineering and Engineering Seismology, Novi Sad, Serbia.

[21] Eurocode 1: Actions on structures, Part 2: Traffic loads on bridges - EN 1991-2, (2003).

[22] Sloan, S. W., (2013). Geotechnical Stability Analysis. Geotechnique, Vol. 63, No. 7.

[23] Schanz, T., Vermeer, P. A., Bonnier, P. G., (1999). The hardening-soil model: Formulation and verification. In R. B. J. Brinkgreve, Beyond 2000 in Computational Geotechnics, Balkema, Rotterdam.

[24] Plaxis, Material Model Manual, (2015).

[25] Duncan, J. M., Chang, C. Y., (1970). Nonlinear analysis of stress and strain in soil. Journal of the Soil Mechanics and Foundations Division, ASCE, Vol. 96.

[26] Eurocode 7: Geotechnical design, Part 1: Basic rules - EN 1997-1: 2005.

[27] Frank, R. et al., (2004). Designer's guide to Eurocode 7 EN 1997-1: Geotechnical Design General Rules. ICE Publishing.

[28] Bond, A., Harris, H., (2008). Decoding Eurocode 7, Taylor \& Fransis, London.

[29] Kostova, St., (2011).Principles for determining of the soil ground bearing capacity according to Eurocode 7. Academic Journal Mechanics, Transport, Communications, Issue 2, No./Aricle ID: 00494, http://www.mtc-aj.com.
[30] Kostova, St., (2011). Designing methods of the soil bearing capacity according to Eurocode 7 and Bulgarian norms, Academic Journal Mechanics, Transport, Communications, Issue 3, No./ Article ID: 00550, http://www.mtc-aj.com.

[31] Kostova, St., (2018). Analysis of the procedure for calculation of the soil ground bearing capacity according to Eurocode 7, Academic Journal Mechanics, Transport, Communications, Vol. 16, No.1.

[32] Markov, I., Totsev, A., (2014). Influence of Dynamic Load on the Ground Anchors Bearing Capacity, 24 European Young Geotechnical Engineers conference EYGEC, UK.

[33] Kerenchev N., Markov I., (2016). Determining the axial bearing capacity of pile based on common methods and comparison with pile load test. Proc. of the 3th International Conference VITGEO2016, Hanoi.

[34] Duncan, J. M., (1996). State of the Art: Limit Equilibrium and Finite-Element Analysis of Slopes. Journal of Geotechnical Engineering, Vol. 122, No. 7.

[35] Kerenchev, N., (2015). Analysis of seismic slope stability and deformations. Dissertation for the degree of PhD, University of Architecture, Civil Engineering and Geodesy, Sofia. 
ABSTRACT

\section{COMPARATIVE ANALYSIS OF DIFFERENT FINITE ELEMENT MODELS OF THE SOIL-BURIED ARCH BRIDGE INTERACTION}

\section{Konstantin KAZAKOV \\ Lena MIHOVA \\ Doncho PARTOV}

Comparative analysis is made of different finite element models of a buried arch bridge which is constructed from precast concrete elements. Two static schemes of the bridge structure are considered - a static scheme of rigid connection between all structure elements and a static scheme of hinged connection between the lateral retaining walls and the vault plate. The modeling is carried out by the Plaxis $2 \mathrm{D}$ software. Two nonlinear constitutive models for soil materials are used - linear elastic-perfectly plastic Mohr-Coulomb's model and advanced elastic-plastic Hardening-Soil model. The Hardening-Soil model is a state-of-the-art scientific achievement which approximates the mechanical behavior of the soil materials with high accuracy using 15 material parameters. Two types of finite elements are used for modeling of the bridge structure: beam and plate elements. The soil-structure contacts are modeled by interface elements of thickness closed to zero. Traffic loads on a road situated above the bridge are assumed according to the model LM1 of Eurocode 1. Mechanical behavior of the bridge is studied by analyses of states in construction and service periods. Analysis of the ground bearing capacity is performed using the shear strength reduction technique.

Key words: arch bridge, soil-structure interaction, hinge connection, rigid connection, plane strain, finite element modeling, constitutive model, traffic loading, Eurocode

\section{SAŽETAK}

KOMPARATIVNA ANALIZA MODELA INTERAKCIJE TLA I LUČNOG MOSTA SA ZEMLJANOM ISPUNOM ZASNOVANIH NA MKE

\author{
Konstantin KAZAKOV \\ Lena MIHOVA \\ Doncho PARTOV
}

$U$ radu su uporedno analizirani različiti modeli ukopanog lučnog mosta izrađenog od montažnih betonskih elemenata, koji su zasnovani na MKE. Razmatrane su dve statičke šeme konstrukcije mosta krute veze između svih elemenata konstrukcije i zglobne veze između bočnih potpornih zidova i zasvedena ljuska. Modeliranje je izvedeno primenom softvera Plaxis 2D. Dva nelinearna konstitutivna modela su korišćena za materijale tla - linearni elasto-plastični Mohr-Coulombov model i unapređeni elasto-plastični model očvršćavanja tla. Model očvršćavanja tla predstavlja visoki stepen naučnog dostignuća kojim se aproksimira mehaničko ponašanje tla sa visokom tačnošću, primenom 15 parametara materijala. Korišćene su dve vrste konačnih elemenata za modeliranje konstrukcije mosta: elementi greda i ploča. Kontakt tla i konstrukcije je modeliran pomoću veoma tankih kontaktnih elemenata. Pretpostavlja se saobraćajno opterećenje na mostu prema modelu LM1 iz EN1991. Mehaničko ponašanje mosta proučeno je analizom stanja konstrukcije i perioda korišćenja. Analiza nosivosti tla izvedena je korišćenjem tehnikom redukcije smičuće čvrstoće tla.

Ključne reči: lučni most, interakcija tla i konstrukcije, zglobna veza, kruta veza, ravne dilatacije, MKE modeliranje, konstitutivni modeli, saobraćajno opterećenje, Evrokod 